\title{
The paradox of the pelagics: why bluefin tuna can go hungry in a sea of plenty
}

\author{
Walter J. Golet ${ }^{1,2, *, * *}$, Nicholas R. Record ${ }^{3, * *}$, Sigrid Lehuta ${ }^{2}$, Molly Lutcavage ${ }^{4}$, \\ Benjamin Galuardi ${ }^{4}$, Andrew B. Cooper ${ }^{5}$, Andrew J. Pershing ${ }^{1,2, * *}$ \\ ${ }^{1}$ School of Marine Sciences, University of Maine, College Road, Orono, ME 04469, USA \\ ${ }^{2}$ Gulf of Maine Research Institute, 350 Commercial Street, Portland, ME 04101, USA \\ ${ }^{3}$ Bigelow Laboratory for Ocean Sciences, East Boothbay, ME 04544, USA \\ ${ }^{4}$ Department of Environmental Conservation, Marine Fisheries Institute, University of Massachusetts Amherst, PO Box 3188, \\ Gloucester, MA 01931, USA \\ ${ }^{5}$ School of Resource and Environmental Management, Simon Fraser University, 8888 University Drive, Burnaby, V5A 1S6, \\ BC, Canada
}

\begin{abstract}
Large marine predators such as tunas and sharks play an important role in structuring marine food webs. Their future populations depend on the environmental conditions they encounter across life history stages and the level of human exploitation. Standard predator-prey relationships suggest favorable conditions (high prey abundance) should result in successful foraging and reproductive output. Here, we demonstrate that these assumptions are not invariably valid across species, and that somatic condition of Atlantic bluefin tuna Thunnus thynnus in the Gulf of Maine declined in the presence of high prey abundance. We show that the paradox of declining bluefin tuna condition during a period of high prey abundance is explained by a change in the size structure of their prey. Specifically, we identified strong correlations between bluefin tuna body condition, the relative abundance of large Atlantic herring Clupea harengus, and the energetic payoff resulting from consuming different sizes of herring. This correlation is consistent with optimal foraging theory, explaining why bluefin tuna condition suffers even when prey is abundant. Furthermore, optimal foraging principles explain a shift in traditional bluefin tuna foraging areas, toward regions with a higher proportion of large herring. Bluefin tuna appear sensitive to changes in the size spectrum of prey rather than prey abundance, impacting their distribution, reproduction and economic value. Fisheries managers will now face the challenge of how to manage for high abundance of small pelagic fish, which benefits benthic fishes and mammalian predators, and maintain a robust size structure beneficial for top predators with alternative foraging strategies.
\end{abstract}

KEY WORDS: Bluefin tuna $\cdot$ Herring $\cdot$ Optimal foraging $\cdot$ Condition $\cdot$ Thunnus thynnus

\section{INTRODUCTION}

Populations of many of the ocean's largest fish have decreased substantially (Myers \& Worm 2003), although the magnitudes of the declines are not as universal across regions and species as previously thought (Sibert et al. 2006). Reducing fishing pressure is a necessary condition for recovery of fish stocks, although it may not be sufficient for all species especially when faced with large changes in

${ }^{*}$ Corresponding author: walter.golet@maine.edu

${ }^{* *}$ These authors contributed equally to this work physical conditions or prey abundance (Chavez et al. 2003, Lehodey et al. 2003, Vert-pre et al. 2013). Small pelagic fish such as sardines, herring, and anchovies comprise $\sim 30 \%$ of global fish landings (Alder et al. 2008). These fish are critical food resources for larger fish, seabirds, and cetaceans, and due to their abundance and trophic position, exert both top-down and bottom-up controls (Cury et al. 2000, Bakun \& Broad 2003). Over the past $50 \mathrm{yr}$, landings of small pelagic species have scaled with increased demand (Jen-

() The authors 2015. Open Access under Creative Commons by Attribution Licence. Use, distribution and reproduction are unrestricted. Authors and original publication must be credited. 
nings et al. 2001, Boyd et al. 2006), but there is growing concern regarding the exploitation of these species (Alder et al. 2008, Tacon \& Metian, 2009). In particular, management strategies have the potential to alter food web dynamics and energy flow through changes in the size structure and abundance of these species (Furness 2002, Frederiksen et al. 2004). Conventional management practices may be inadequate to maintain sufficient biomass of small pelagic species for fisheries and the predators which depend on them (Pikitch et al. 2012). The impact of changes in pelagic fish stocks may be particularly high for marine mammals (Spitz et al. 2012) or other large warmbodied fish such as tunas whose physiology is geared toward high energetic returns while foraging.

The Atlantic bluefin tuna Thunnus thynnus is a highly migratory species with an Atlantic-wide distribution (Mather et al. 1995), exploited by multiple countries across the Atlantic basin due to the high value of its flesh (Bestor 2004). Maintaining metabolic costs for bluefin tuna, like other large marine predators requires high rates of energy intake (Spitz et al. 2012) and their migratory patterns and foraging behaviors are adapted to exploit dense aggregations of lipid rich prey (Chapman et al. 2011).

In the western Atlantic, bluefin tuna are distributed across the Northwest Atlantic Shelf from June through to October (Wilson et al. 2005, Galuardi et al. 2010), and the Gulf of Maine is one of the most important foraging grounds (Mather et al. 1995, Wilson et al. 2005, Galuardi et al. 2010). Mid-trophic levels in this region are dominated by small lipid-rich planktivorous fish (Lawson et al. 1998), principally Atlantic herring Clupea harengus, the bluefin tuna's preferred prey (Chase 2002, Estrada et al. 2005, Pleizier et al. 2012). During the summer foraging period, bluefin tuna build up large reserves of fat in their muscles and perigonadal mesenteric tissues. The quantity of fat determines migratory capacity (Chapman et al. 2011) and reproductive output (Medina et al. 2002, Knapp et al. 2014), and is a primary factor that determines the market price of an individual fish (Bestor 2004).

The population of herring, the primary forage species for bluefin tuna in the Gulf of Maine (Chase 2002), experienced substantial fluctuations in abundance since the 1960s due to harvesting pressure and environmental variability (Overholtz \& Friedland 2002). Since rapid depletion during the 1970s, the herring stock has rebounded to historically high levels of abundance beginning ca. 1990 (Overholtz \& Friedland 2002). Given that herring is the primary forage for bluefin tuna and that herring abundance was high, foraging conditions in the Gulf of Maine should have been favorable for bluefin tuna thereby increasing their lipid accumulation, boosting reproductive output, and increasing their economic value. During this period of high herring abundance, however, body condition of bluefin tuna based on market grades declined in the Gulf of Maine (Golet et al. 2007).

Based on recent stock assessments by the International Commission for the Conservation of Atlantic Tunas (ICCAT), bluefin tuna spawning stock biomass (SSB) is down approx. $70 \%$ from levels observed in the early 1970s (ICCAT 2010). Despite $30 \mathrm{yr}$ of regulated catches in line with scientific advice, and a population rebuilding plan implemented in 1998, there have been minimal increases in SSB for the western stock and low levels of recruitment relative to observations in the early 1970s. Assuming these regulatory measures were correct, a lack of rebuilding could suggest that variables unaccounted for in assessments (e.g. changes in ecosystem conditions) may be inhibiting population rebuilding. In fact, the stock assessment for bluefin tuna is run based on 2 different scenarios; a high and low recruitment scenario. The latter suggests that conditions are no longer capable of sustaining the high recruitment observed in the early 1970 s due to ecosystem shifts either on the foraging or spawning grounds.

We evaluated the somatic condition of bluefin tuna throughout the entire Gulf of Maine over a $30 \mathrm{yr}$ period of high and low herring abundance to determine mechanisms for the observed paradox of low bluefin tuna condition during a period of presumed high foraging profitability (i.e. the 'paradox of the pelagics'). We quantified the energetic returns of bluefin tuna foraging on different size spectra of herring across different regions of the Northwest Atlantic shelf using an optimal foraging model. A time series of bluefin tuna catch locations was created from logbook data collected from the commercial bluefin tuna fishery to check for shifts in distribution as they related to changes in foraging conditions.

\section{MATERIALS AND METHODS}

\section{Condition analysis}

\section{Bluefin tuna}

This study is based on body length and weight data of bluefin tuna individuals that were commercially harvested between 1980-2009; data were acquired from the National Marine Fisheries Service (NMFS). Each entry included the date landed, length, weight, 


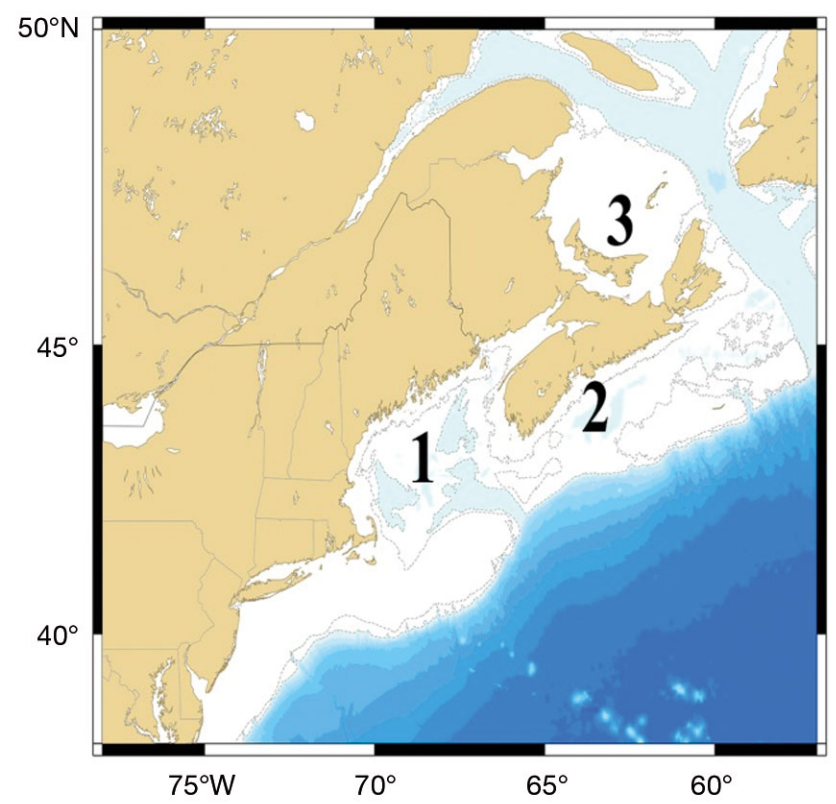

Fig.1. Northern foraging grounds for Atlantic bluefin tuna Thunnus thynnus in (1) the Gulf of Maine, USA, (2) Scotian Shelf and (3) the Gulf of St. Lawrence, Canada

gear type (i.e. rod and reel, purse seine, longline, harpoon), and catch location (10 statistical areas from the Gulf of Mexico to the Gulf of Maine). We defined our research area to include the historical and current foraging grounds for adult $(>185 \mathrm{~cm})$ bluefin tuna. These areas included the Gulf of Maine, Georges Bank and waters north of Montauk, NY (NMFS Statistical Areas 1-6) from 1 June to 31 October (Fig. 1). All lengths and weights were standardized to current reporting requirements for length (curved fork length, CFL) and weight (round weight, fish intact) using conversion factors accepted by the Standing Committee on Research and Statistics within the ICCAT convention (Parrack \& Phares 1979). Outliers in length-weight relationships (based on quality checks across all fish sizes and gear types) were removed with a standard deviation filter that calculated the mean fish size across all years, stratified by day (from 1 June to 31 October), and removed all values lying $>3 \mathrm{SD}$ from each respective size class mean. To reduce potential bias associated with combining different gear types, only rod and reel fish (general category) were included for further analysis. This gear type accounts for approx. $75 \%$ of landings in the region. In this analysis, the lower and upper bounds for lengths of fish were from the current commercial min. size (185 cm CFL) to a cut-off point (305 cm CFL), where sufficient numbers of fish allowed for statistical comparison. The current min. size coincides with a point in development where bluefin tuna transition from a period of rapid growth in length to girth, adding seasonal lipid stores (Mather \& Schuck 1960). Collectively, this filtering reduced our initial database from 127742 to 70466 individual length and weight records.

\section{Atlantic herring}

The Maine Department of Marine Resources (USA) and the Canadian Department of Fisheries and Oceans have been collecting herring from commercial fishing fleets for over 3 decades to monitor basic biological parameters. Individual entries from these databases for each fish include date sampled, length, weight, age, sex, and gear type. Both the USA and Canadian databases were filtered using the same temporal boundaries as described for bluefin tuna (June through October). In the case of the Maine herring database, spatial boundaries were set according to those outlined in the bluefin tuna section for historic and current bluefin tuna distribution. Only herring sampled from mobile fishing gear (e.g. purse seine, trawl) were used in this analysis since the herring fleet's distribution overlaps with known foraging grounds of bluefin tuna. Fixed gear (e.g. stop seines, weirs) in the Gulf of Maine occur in areas with limited bluefin tuna foraging activity and typically catch herring absent from diet studies of bluefin tuna $(<180 \mathrm{~mm}$ straight fork length). Herring sampled from mobile gears ranged from 73-395 mm straight fork length and $2-572 \mathrm{~g}$ round weight. The original Maine database contained 265900 individual entries. We filtered the database removing herring smaller than $180 \mathrm{~mm}$, and outliers in the length-weight relationship following the same protocols used in the bluefin tuna database. This procedure reduced the number of individual herring to 160899 . For the Canadian herring database, we confined our herring samples to regions with historic and current distributions of bluefin catches (Hanke et al. 2013). Areas used for this analysis included 4W (Scotian Shelf north of Halifax, NS), and $4 \mathrm{~T}$ (Gulf of St. Lawrence, Prince Edward Island) (Fig. 1). We excluded the Bay of Fundy and southern Nova Scotia (4X) since this area is adjacent to the Gulf of Maine. Outliers in the length-weight relationship were removed using the same standard deviation methods described for bluefin tuna. After filtering this database there was a total of 289907 individual herring length and weight records available for analysis. We acknowledge the potential for gear selectivity in these data sets given their origin is from the commer- 
cial fishery. The herring fishery in the Gulf of Maine has undergone considerable regulatory changes which have altered the proportion of the catch by gear type. The biological sampling database does not distinguish between mobile gear types. Thus, it is not possible to explore potential gear selectivity or relate to which gear these samples came from. However, the Maine Department of Marine Resources does collect landings information from commercial herring fishermen and we used this as a proxy for how the composition of our samples may have changed. From 1980-1994, purse seines accounted for more than $80 \%$ of the herring captured by mobile gear. Trawl landings began to increase in 1993, and by 1997, approx. equal percentages of herring were landed by trawl and purse seine. Between 2000-2006, trawl gear landed approximately $30 \%$ more herring than purse seine and, from 2007-2009, the trend reversed again. However, herring mean weight and length declined throughout the time series and did not change as the ratio of landings changed between gear types. Given the sizes of the mesh, no. of fish, and the time and areas sampled, it is assumed that changes in lengths and weights of herring are representative of population level changes and not fleet selectivity. The biological samples collected from the Canadian commercial herring fishery are from purse seine gear only.

Seasonal foraging activity in both bluefin tuna and herring lead to seasonal cycles of weight accumulation. Since we were interested in year-to-year changes in condition, we accounted for these cycles using a generalized additive model (GAM) (Hamming 1973, Hastie \& Tibshirani 1990, Maravelias et al. 2000). The dependent variable (weight) was modeled as a function of 2 independent variables (length, day of year). This non-parametric regression is less restrictive regarding the distribution of the data and weight can be modeled as the additive sum of nonparametric smooth functions of covariates. In this analysis, the least squares estimate in the regression was replaced with a smoother (s). The general form of the GAM (Hastie \& Tibshirani 1990) was:

$$
E(y)=g^{-1}\left(\beta_{0}+\sum_{k} S_{k}\left(X_{k}\right)\right)
$$

where $E(y)=$ the expectation of the random variable $y$ (here bluefin or herring weight as a function of time), $g()=$ the link function between the response and additive predictor, $\beta_{0}+\Sigma_{k} S_{k}(X), \beta_{0}=$ an intercept term, $X_{k}=$ the value of the $k^{\text {th }}$ covariate, $S_{k}()=$ smooth functions of the $k$ covariates. Here the dependent variable (bluefin or herring weight) is modeled as a function of day of year and individual fish length. Af- ter fitting the model to each of the 2 datasets, a mean weight was calculated for a given length by day of year across years. To calculate the anomalies we subtracted the observed weight of each fish from the expected weight in the length-weight relationship and standardized by dividing this value by the expected weight. That is, the anomaly value for a given year is the mean of $[W(y)-E(y)] / E(y)$ for all weight measurements $W(y)$ and expected weights $E(y)$ across all size classes of fish and all days within that year (see Fig. 2A). We applied the same calculation for annual herring weight anomalies (see Fig. 2B).

\section{Foraging model}

A payoff-maximizing prey model was used to compute the average relative energetic payoff rate for a tuna-like predator foraging on a given diet of herring. Implicit in the use of this model is the assumption that herring, as a prey resource, is not scarce. This assumption breaks down for very low prey abundances; however, herring abundance was relatively high in the Gulf of Maine throughout the time series. We followed the methodology and notation of the 'Prey Model' (Stephens \& Krebs 1986, §2.2) for the foraging model described below. Following that formulation, the payoff rate for a given diet is:

$$
P=\frac{\sum_{i=1}^{n} p_{i} \lambda_{i}\left(\tilde{e}_{i}+s h_{i}\right)}{1+\sum_{i=1}^{n} p_{i} \lambda_{i} h_{i}}
$$

where $n$ is the number of prey types in the diet, $i$ indexes prey type (in this case, prey size), $h_{i}$ is the expected handling time per prey item, $\tilde{e}_{i}$ is the net energy gain per prey item, $\lambda_{i}$ is the encounter rate, $s$ is the energetic search cost per unit time (so that $s h_{i}$ is the energetic search cost per prey item), and $p_{i}$ is the probability that an item of type $i$ will be attacked upon encounter. Stephens \& Krebs (1986) demonstrate that under the payoff-maximizing assumption, $p_{i}$ is either 0 or 1 .

Encounter rate is defined as:

$$
\lambda_{i}=\lambda_{\mathrm{T}} \frac{N_{i}}{\sum_{i=1}^{n} N_{i}}=\lambda_{\mathrm{T}} \frac{N_{i}}{N_{\mathrm{T}}}
$$

where $N_{i}$ is the number of individuals of size $i$ (weight, $g$ ), $N_{\mathrm{T}}$ is the total number of individuals, and $\lambda_{\mathrm{T}}$ is the encounter rate for all prey. Energy was obtained from mass using a constant energy density conversion, $k_{i}$ that is, $\tilde{e}_{i}=k m_{i}$. Prey type was binned 
by the mass of the prey in increments of $10 \mathrm{~g}$. We assume a single handling time $h$ across size classes, and we assume that variability in caloric content of herring of a particular weight is small (Lane et al. 2011) and thus, that the payoff of eating a particular prey is proportional to its mass.

One of the results derived from this model by Stephens \& Krebs (1986) is that the predator's diet will be defined by a threshold prey size $x$, where the predator eats any prey larger than $x$ when encountered and ignores fish smaller than $x$. Using this result, and the substitutions in Eqs. (2) \& (3), the payoff for a diet $x$ is then:

$$
P(x)=\frac{\lambda_{\mathrm{T}}\left[\sum_{i=x}^{n} N_{i} m_{i}\right]-s N_{\mathrm{T}}}{N_{\mathrm{T}}+h \lambda_{\mathrm{T}} \sum_{i=x}^{n} N_{i}}
$$

whereby the optimal diet in this case is given by the value $x^{*}$ for which $P(x)$ is maximal. The optimal diet and resulting payoff were found by testing all values of $x$, using the full range of prey sizes represented in the data. Parameter estimates were identified using a combination of first-hand observations and literature values. The basic assumption is that food is not limiting, and by implication, that foraging decisions are those made while in the presence of prey, rather than decisions regarding when, where, and how long to search for schools of prey. Presumably, the latter would take on a more substantial role as food becomes scarce; however, current prey levels are extremely high in the Gulf of Maine. Correlation analysis was conducted between the time series for bluefin tuna weight anomalies and herring weight anomalies, herring SSB, minimal herring mass $(g)$ and herring profitability.

\section{Parameter estimation and sensitivity}

There are 3 parameters to estimate: $s$ (search cost), $h$ (handling time), and $\lambda_{\mathrm{T}}$ (encounter rate). The results presented below used best estimates for these parameters; however, due both to lack of information and to the complexity of the feeding process, there is large uncertainty around these estimates. Therefore, upper and lower bounds were also estimated for each parameter, representing extreme cases, to test the sensitivity of our results to the estimated parameterization. These estimates considered tuna actively foraging within schools of herring (as opposed to searching for schools or prey patches), with an assumed constant energy density (Lawson et al. 1998) for the prey of $k=9.4 \mathrm{~kJ} \mathrm{~g}^{-1}$.
Search cost was computed as the metabolic expenditure during foraging, estimated from values reported in the literature for other tuna species. Routine metabolic rates of southern bluefin tuna range from a baseline of around $350 \mathrm{mg} \mathrm{O} \mathrm{Kg}^{-1} \mathrm{~h}^{-1}$ to upwards of $1200 \mathrm{mg} \mathrm{O}_{2} \mathrm{~kg}^{-1} \mathrm{~h}^{-1}$ in extreme cases during feeding events (Fitzgibbon et al. 2008). For a $200 \mathrm{~kg}$ tuna, this ranges from 70000-240000 $\mathrm{mg} \mathrm{O}_{2} \mathrm{~h}^{-1}$. Using the conversion factor (Olson 1982) $1 \mathrm{cal}=3.359 \mathrm{mg} \mathrm{O}_{2} \mathrm{~h}^{-1}$ and converting $\mathrm{cal} \mathrm{h}^{-1}$ to $\mathrm{kJ} \mathrm{s}^{-1}$ gives a range of 0.02-0.08 $\mathrm{kJ} \mathrm{s}^{-1}$. These represent upper and lower bounds, and $s=0.05 \mathrm{~kJ} \mathrm{~s}^{-1}$ was used as an intermediate estimate.

Deck-based observations of bluefin tuna feeding suggest very rapid consumption of fish. Bluefin tuna are ram feeders, using burst swimming to force prey into their mouth. A lower bound on handling time is therefore on the order of a few seconds. Handling time should also consider gut content limitations, however, as a bluefin tuna consuming a $100 \mathrm{~g}$ herring every $5 \mathrm{~s}$ could double its own mass in just a few hours. A handling time of $10 \mathrm{~s}$ is therefore a reasonable estimate for a lower bound. An upper bound on handling time can be estimated from ingestion rates $\left(I, \mathrm{~kJ} \mathrm{mo}^{-1}\right)$ predicted by an energetics model: $I=a L^{b}$, whereby $L$ is the length of the tuna $(\mathrm{cm})$, and $a$ and $b$ are free parameters. Using the range of values from a bluefin tuna bioenergetics model (Chapman et al. 2011), and assuming a mean prey of $100 \mathrm{~g}$ at $9.4 \mathrm{~kJ}$ $\mathrm{g}^{-1}$, gives an upper bound for handling time of around 20 min, an unrealistically high estimate. Bluefin tuna spend an estimated $30-45 \%$ of their time in the Gulf of Maine feeding in prey patches (Gutenkunst et al. 2007). Accounting for this factor puts an upper bound for handling time at 400-600 s, still representing a conservatively high estimate. Bounds for handling time are therefore $10-600 \mathrm{~s}$, with $h=30 \mathrm{~s}$ as the intermediate estimate.

It is difficult to estimate the rate at which an actively feeding bluefin tuna makes a foraging decision. Therefore a range spanning 3 orders of magnitude was used, from $\lambda_{\mathrm{T}}=0.01$ herring $\mathrm{s}^{-1}$ to 1 herring $\mathrm{s}^{-1}$, with $\lambda_{\mathrm{T}}=0.1$ herring $\mathrm{s}^{-1}$ as the intermediate estimate. Output from the optimal foraging analysis created 2 time series: profitability of the herring assemblage $P(x)\left(\mathrm{kJ} \mathrm{s}^{-1}\right)$ and the mass of the smallest fish in an optimally foraging bluefin tuna's diet $\left(x^{*}\right)$. To test sensitivity of the results on parameter choice, correlation coefficients were computed between profitability and bluefin tuna weight anomalies, testing the full parameter space (bounded by upper and lower bounds for each parameter and subdivided by hundredths). Correlations were highly statistically signifi- 
cant ( $\mathrm{p}<0.001$ ) throughout the parameter space, with $\mathrm{r}^{2}$ values ranging from 0.60 to 0.65 , suggesting that the main results are not sensitive to parameter choice.
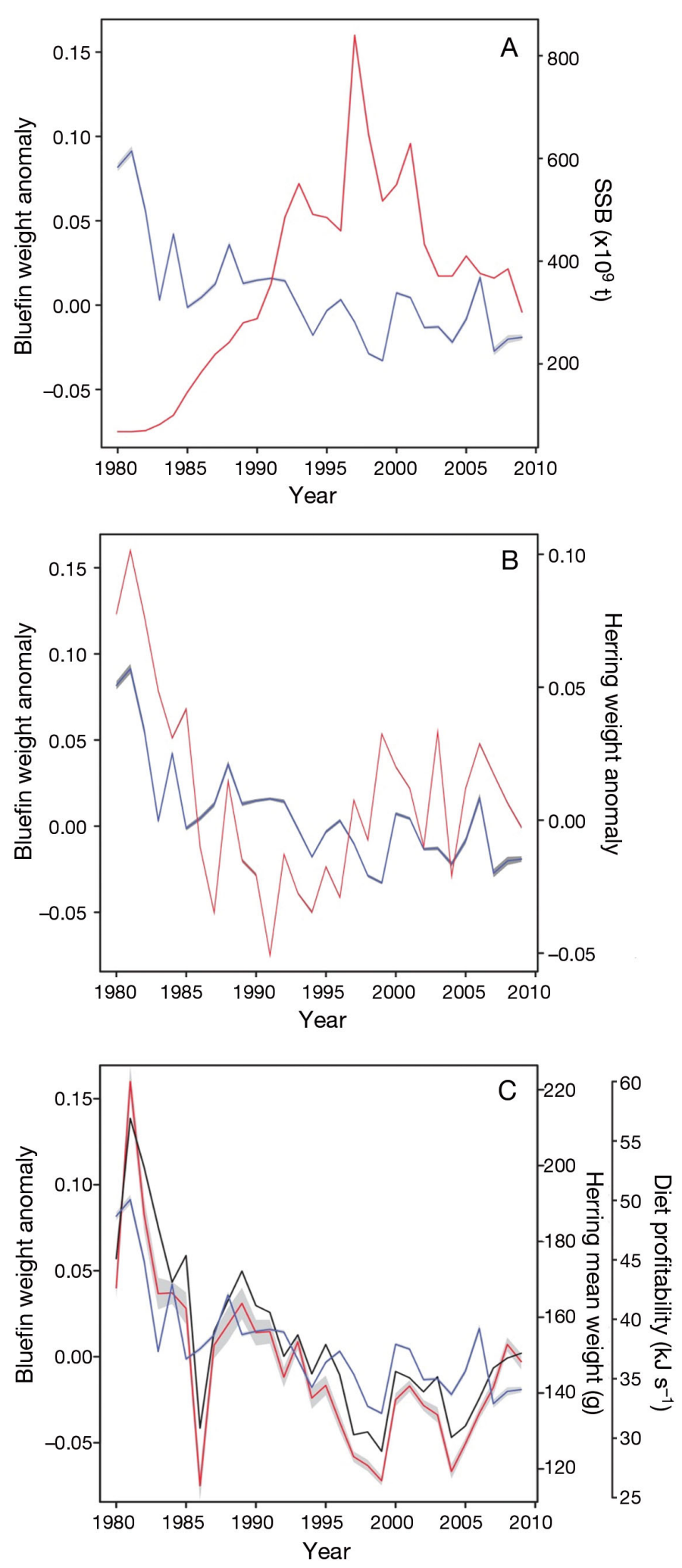

\section{RESULTS}

From 1980-2009, the body condition of bluefin tuna declined. Body condition of bluefin tuna dropped rapidly, was at intermediate levels during the majority of the 1980s, and then declined further in the early 1990s (Fig. 2A).

The decline in bluefin tuna weight anomalies in the early 1990s tracked a decline in herring weight anomalies (Fig. 2B). Although, the correlation between the bluefin tuna and herring weight anomaly series is significant $\left(\mathrm{r}^{2}=0.33, \mathrm{p}<0.01\right)$, the relationship weakens during the last half of the time series due to an increase in herring condition that was not matched by an increase in bluefin tuna condition. The lack of correlation in the second half of the time series and the dominance of younger $(<4 \mathrm{yr}$ old) but better conditioned herring suggest a synergistic interaction between bluefin tuna condition and herring size. To test this hypothesis, we developed a time series of mean herring weight $(g)$ for the Gulf of Maine. This time series exhibits a strong and consistent relationship with bluefin tuna weight anomalies $\left(r^{2}=0.61, p<0.01\right.$, Fig. 2C). The association between declining bluefin tuna weight anomalies and mean herring weight seems obvious, however, the question still remains as to why a $500 \%$ increase in herring abundance was insufficient to make up for the decline in mean herring weight.

We interpret the correlation between bluefin tuna weight anomalies and mean herring weight as evidence of an optimal foraging strategy occurring in sub-optimal conditions. Optimal foraging theory predicts that predators should always consume the most profitable prey items encountered (Stephens \& Krebs 1986); for bluefin tuna, this is the largest size class of herring. To test this assumption, we

Fig. 2. (A) Estimated spawning stock biomass (SSB) for Atlantic herring (Clupea harengus) complex (red line) and weight anomalies for Atlantic bluefin tuna Thunnus thynnus (blue line) $(\mathrm{n}>70000)$ in the Gulf of Maine; these series are negatively correlated $\left(r^{2}=0.47, p<0.01\right)$. (B) Weight anomalies of Atlantic herring (red line) $(n>260000)$ and Atlantic bluefin tuna (blue line) in the Gulf of Maine; these series are positively correlated $\left(r^{2}=0.33, p<0.01\right)$. (C) Atlantic bluefin tuna weight anomalies (blue line), mean weight of herring from the Gulf of Maine stock complex (red line), and the diet profitability (black line) from the optimal foraging model. There were significant relationships between bluefin tuna weight anomalies and the mean weight of Atlantic herring $\left(\mathrm{r}^{2}=0.61, \mathrm{p}<0.01\right)$, and between bluefin tuna weight anomalies and the diet profitability of Atlantic herring $\left(\mathrm{r}^{2}=0.62\right.$, $\mathrm{p}<0.01)$. Shaded regions represent the $99 \% \mathrm{CI}$ 

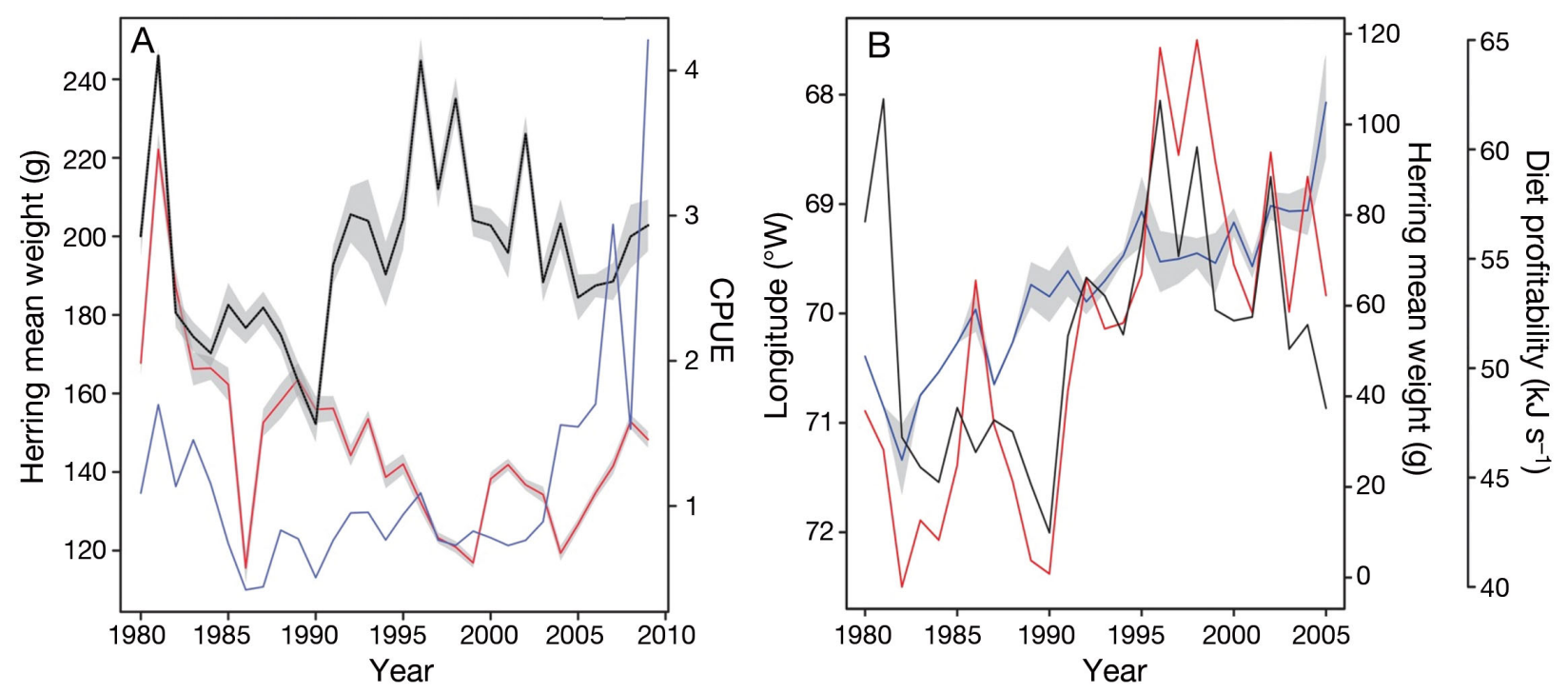

Fig. 3. Regional differences in herring Clupea harengus mass and profitability. (A) Mean weight of Atlantic herring from the Gulf of Maine (red line) and from Canadian waters: Scotian Shelf and Gulf of St. Lawrence, combined (black line). Bluefin tuna Thunnus thynnus catch per unit effort (CPUE) in the Gulf of St. Lawrence (blue line) increased rapidly since 2002. (B) Position of bluefin tuna schools observed or captured by the commercial fleet (blue line), the difference in mean herring weight between the Canadian and Gulf of Maine waters (red line), and the diet profitability for Canadian waters (black line). The movement of tuna schools to the east was positively correlated with the difference between the mean herring weight in the Gulf of Maine and the mean weight in Canadian waters $\left(r^{2}=0.40, p<0.01\right)$. Shaded regions represent the $99 \%$ confidence intervals

used the Stephens \& Krebs (1986) optimal foraging prey model for bluefin tuna foraging within a patch of herring. The resulting time series of diet profitability was strongly correlated with bluefin tuna weight anomalies $\left(r^{2}=0.62, p<0.01\right.$, Fig. $\left.2 C\right)$, and this relationship was not sensitive to parameter choices.

While mean herring weight in the Gulf of Maine declined by $55 \%$ between 1981 and 2010 (Fig. 3A), a herring weight index for the adjacent Scotian Shelf and Gulf of St. Lawrence, and optimal foraging model time series were relatively steady and remained elevated above the Gulf of Maine index throughout the record (Fig. 3). The time series of herring weight indicated that larger herring were still available on the Canadian Scotian Shelf and Gulf of St. Lawrence, even as their abundance declined in the Gulf of Maine. The steady decrease in herring mean weight in the Gulf of Maine correlates with the shift in the distribution of adult bluefin tuna schools, which moved progressively eastward (Fig. 3B). There was a significant relationship between the difference in herring weight from the Gulf of Maine and Canadian waters (Scotian shelf and Gulf of St. Lawrence) and the timing of the eastward movement of bluefin tuna catch locations $\left(r^{2}=0.40\right.$, p $<0.01$, Fig. 3B).

\section{DISCUSSION}

The results from this study support the observations of Golet et al. (2007) that the condition of bluefin tuna in the Gulf of Maine has declined. In the present study, however, bluefin tuna condition was evaluated over a much longer time period and throughout the entire Gulf of Maine whereas Golet et al. (2007) only tracked condition of bluefin tuna from a single spatially restricted area. The Gulf of Maine is an important foraging ground for bluefin tuna (Mather et al. 1995) where these fish spend up to 6 mo consuming high energy prey such as herring (Chase 2002). Following depletion during the 1970s, herring stocks in the Gulf of Maine rebounded to historically high levels of abundance around 1990 as stocks on the offshore banks were rebuilt (Overholtz \& Friedland 2002, Melvin \& Stephensen 2007). The decline of bluefin tuna condition during a period of such high prey abundance is contrary to expectations, particularly since foraging models suggest the proportion of herring in the bluefin diet has increased (Overholtz 2006) across the time series presented in this paper. Conditions on the foraging grounds during the 1990s and 2000s for western bluefin tuna appear favorable given the high abundance of their main prey, herring (Chase 2002) and should have resulted in bluefin tuna 
with higher than average weight anomalies. This scenario (i.e. high prey abundance increased predator success) is typical for many species (Marshall et al. 1999, Österblom et al. 2008); yet in this study, bluefin tuna body condition is inversely correlated with prey abundance. We hypothesize that the decline in bluefin tuna condition in the Gulf of Maine is a consequence of a foraging strategy that depends on larger, more energetically profitable prey, in this case herring.

We used several approaches to evaluate this hypothesis. First, we developed a time series of herring weight anomalies which was significantly correlated with changes in the condition of bluefin tuna. Despite the significance of this relationship, however, the correlation became weaker in the 1990s which we attribute to the increase in shorter, but better condition herring $(<3 \mathrm{yr}$ old $)$. We tested this hypothesis by constructing a time series of mean herring weights and correlated these with bluefin tuna weight anomalies. The correlation between mean herring weights and bluefin weight anomalies was much stronger and suggests that bluefin require a broad size spectrum of Atlantic herring in order for their foraging to be profitable. Still, the question remains why a $500 \%$ increase in herring abundance would not substitute for the loss of larger individuals in the herring population. We attribute this to a foraging strategy that relies on optimizing energy intake by consuming the largest prey in the population. We tested this by developing a foraging model that predicts the energetic outcomes of bluefin foraging within herring schools composed of different sizes of herring. The subsequent time series (energy/time) was highly correlated with the changes in bluefin tuna weight anomalies, supporting our hypothesis that the most successful foraging environments for bluefin tuna are those with the largest prey.

Despite numerous examples of predator success in environments with high prey abundance, there is growing evidence that predators, particularly ones with higher metabolic rates, use different strategies to maximize energy intake (Spitz et al. 2012). This is in line with recent studies which identify benefits to growth and reproduction for species with foraging strategies that select a prey base with high energetic value and/or a broad size distribution (Pazzia et al. 2002, Sherwood et al. 2002, Spitz et al. 2012, Giacomini et al. 2013), as opposed to one which relies entirely on abundance. Tunas, particularly bluefin, have elevated metabolic rates relative to other teleosts (Brill 1996), making them closer (in metabolic demand) to marine mammals and seabirds in that they require high rates of energy intake to satisfy their basal metabolic rates, large migratory (Block et al. 2005, Wilson et al. 2005, Galuardi et al. 2010) and reproductive capacities (Medina et al. 2002, Knapp et al. 2014). Given these demands, it is not surprising that bluefin tuna consume a disproportionate amount of herring, which have high lipid content and energetic values relative to other abundant prey resources on the Northwest Atlantic shelf (Lawson et al. 1998). This may be why, despite a decrease in Atlantic herring size distribution, substantial changes in herring abundance and the availability of alternative prey resources (sandlance, bluefish, mackerel), bluefin tuna diet has been stable over time (Chase 2002, Pleizier et al. 2012, Logan et al. 2014).

Results from our foraging model are in line with a number of other studies which show that foraging strategies, particularly in pelagic environments, are sensitive to the size of prey. Giacomini et al. (2013) identified foraging costs as the mechanism for differences in prey profitability whereas our model suggests handling time is the limiting factor given it does not scale with prey size. In other words, given that bluefin tuna are ram feeders, the time to process a large or small herring is the same, but the energetic payoff between the two is quite different (Lane et al. 2011). Both our model and Giacomini et al. (2013) demonstrate that particulate feeders in pelagic environments need to target larger prey. Despite mechanistic differences, both studies emphasize the advantages of consuming fewer larger prey vs. the more abundant, smaller ones. Likewise, in the case of bluefin tuna in this study, animals with similarly high metabolic demands and high energy content diets (e.g. sea birds and sea lions) have had trouble adjusting to changes in prey quality (Diamond \& Devlin 2003, Rosen \& Trites 2004).

There are several alternative explanations for changes in the condition of bluefin tuna. Consumption of other less energetic prey species could reduce energetic payoffs and results in lower somatic condition. Chase (2002) identified sandlance as an important prey item in stomachs collected from bluefin tuna in the Gulf of Maine and showed that bluefin tuna feed on bluefish, cephalopods and mackerel. However, sandlance were found in 2 primary locations, whereas herring were observed in all stomachs across the region; and cephalopods, mackerel and bluefish had minor contributions across all areas. Similarly, Logan et al. (2014), using stomach content analysis and stable isotopes from bluefin tuna collected between 2004-2008, suggest herring is still the most important dietary item for bluefin tuna in the Gulf of Maine. Pleizier et al. (2012) identified herring 
as the dominant prey item in the stomachs of bluefin tuna in the Gulf of St. Lawrence and Nova Scotia. Herring accounted for $>50 \%$ wet wt of each stomach with the next highest contribution (10\%) coming from mackerel. The percentage of herring in the diet appears rather consistent both between regions and across decades, supporting the idea that bluefin tuna require high quality prey to satisfy their energetic needs despite being considered a generalist predator.

Given the consistency of herring in the bluefin diet and the increase in consumption over the past 2 decades (Overholtz 2006), it is likely that changes in the quality of herring are contributing to the observed declines in bluefin tuna condition. The continued decline in mean weight and length of herring suggest changes in their growth patterns which may come from top-down or bottom-up processes. The lack of older and/or heavier herring could be a result of fishing selectivity, removing older age classes; however, assessments indicate that fishing mortality for Atlantic herring is low (TRAC 2009). Observed changes in body condition of herring has been linked to density dependence (Melvin \& Stephensen 2007), but substantial bottom-up changes have also occurred in the Gulf of Maine, which may have affected herring growth (Greene et al. 2013) by altering foraging conditions for herring. Thus, the paradox of low bluefin tuna body condition and high herring abundance results from an interaction between the bluefin tuna foraging strategy and a shift in the herring size spectrum towards smaller fish; the exact mechanism for this remains unclear.

However, our results suggest bluefin tuna are responding to changes in foraging conditions in the Gulf of Maine. Supporting this hypothesis is the high catch per unit effort in Nova Scotia and the Gulf of St. Lawrence (Hanke \& Neilson 2011) and our analysis which shows the mean position of bluefin tuna catches in the Gulf of Maine shifting eastward out of the Gulf of Maine and across the USA-Canadian boundary (Fig. 3B) (Golet et al. 2013). We hypothesize that as mean weight of Atlantic herring declined, foraging profitability declined and fewer bluefin tuna have remained in the Gulf of Maine, analogous to the 'win-stay, lose-shift' hypothesis (Randall \& Zentall 1997). As a consequence of lower foraging quality, more individuals are likely to have joined other contingents and sought additional regions for larger and presumably more profitable prey, in this case larger herring. Our time series of herring profitability on the Scotian Shelf and Gulf of St. Lawrence illustrates that foraging conditions were much better there than in the Gulf of Maine. Our time series of bluefin tuna school locations correlated with the difference in foraging profitability suggesting bluefin tuna were responding to lower foraging conditions and moving to these high profitable foraging areas. Electronic tagging data also suggests that bluefin tuna tagged in regions of high herring profitability (Scotian Shelf and Gulf of St. Lawrence) returned annually to those areas (Galuardi et al. 2010) and their migrations largely avoided the Gulf of Maine during times when herring mean weight (profitability) was low. Furthermore, the development of a commercial winter (December/ January) bluefin fishery off the coast of North Carolina in the mid 1990s may have been a result of declining foraging conditions in the Gulf of Maine. In this region, bluefin tuna foraged on another high-lipid and -energy prey, Atlantic menhaden Brevoortia tyrannus (Butler et al. 2010), and there appears to be migratory connectivity between bluefin tuna from the Gulf of Maine to the North Carolina region (Wilson et al. 2005). Reduced foraging opportunities in the Gulf of Maine may have led to the emergence of the winter bluefin tuna fishery off the Carolinas and the retention of these fish as they sought additional foraging locations to increase lipid stores.

A reduction in lipid stores can have profound effects on fish life history, but identifying exactly what will happen and what aspects of life history will be affected is complicated. Faced with reduced energy, spawning age fish can reduce growth and reallocate more reserves to gonadal investment (Kjesbu et al. 1991). Such a strategy can maintain fecundity in times of reduced condition, but may also contribute to higher rates of post-spawning mortality (Lambert \& Dutil 2000). Alternatively, fish may skip spawning in times of reduced condition (Rideout et al. 2005) or change reproductive output (fewer eggs, lower quality) for females (Lambert \& Dutil 2000). Given the effect of total lipid content on egg production (Marshall et al. 1999), the influence of prey quality on predator life history parameters (Rosen \& Trites 2004, Jørgensen et al. 2006) and the relationship between bluefin tuna weight and fecundity (Medina et al. 2002, Knapp et al. 2014), a reduction in bluefin tuna condition on the foraging grounds could have affected reproductive output, and appears to have changed historical distributions. Although we did not directly estimate potential losses in reproductive output, given a fecundity of 28 eggs $^{-1}$ (Knapp et al. 2014) declines in the amount of lipids on the foraging grounds is likely to affect reproduction, particularly since wellconditioned fish have a higher weight-specific reproductive rate (Scott et al. 2006). Changes in lipid content also affect the sale price of bluefin tuna, with fat 
content having a large influence on selling price (Bestor 2004). Fat content is also one of the most important variables determining whether or not a bluefin tuna stays on the domestic market or is shipped to Japan (where returns are typically higher). Markets, particularly those for highly migratory species are

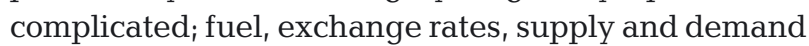
among other things all contribute to the selling price of a fish. However, given the large influence fat content has on the overall quality of the fish and to which market it will be shipped, the loss in lipids for bluefin tuna in the Gulf of Maine is likely to have reduced ex-vessel prices. In summary, changes in the ability of bluefin tuna to accumulate lipids on their foraging grounds can have far reaching consequences.

According to recent assessments, spawning stock biomass of western Atlantic bluefin tuna has not recovered to early 1970 s levels despite the implementation of a rebuilding plan in 1998. In addition, total allowable catches have been in line with scientific advice for over 2 decades. If fishing mortality were the sole factor limiting population recovery, levels of fishing mortality set by management should have allowed this stock to rebuild much faster than currently observed, even for a species with long generation times like bluefin tuna. A slow recovery may be related to fishing mortality set too high, despite the scientific advice, or could be the results of environmental factors affecting life history (growth, reproduction, migration) or synergistic effects between the two. At this time, it is difficult to say whether or not changes in foraging conditions in the Gulf of Maine have led to population level effects.

Our results have direct implications for the management of herring and other small pelagic fish which serve as energy conduits in many temperate systems. Approximately one third of marine fish landings are small pelagic species (Alder et al. 2008). Their high energy density, abundance, and schooling behavior make them attractive to commercial fisheries, and critical food resources for top predators including larger fish, seabirds, and whales (Weinrich et al. 1997, Pikitch et al. 2012, 2014). Ecosystembased fisheries management requires managers and scientists to quantify trade-offs between managed populations by adopting co-management strategies. Standard predator-prey relationships imply that reducing fishing pressure on mid-trophic level species should be beneficial for higher trophic levels. In fact, a major recommendation from a recent small pelagics review (Pikitch et al. 2012, 2014) suggested catch levels for small pelagics should be reduced by $50 \%$ in some regions to increase abundance and account for the high volatility of these populations. The decline in bluefin tuna condition, despite high prey biomass in the Gulf of Maine, suggests that managing for high abundance at middle trophic levels does not guarantee the success of all top predators. In fact, it suggests that for some upper level predators, the quality of the prey may be more important than the overall abundance.

Although the interactions are complex, fisheries management can directly influence the size structure of managed stocks, primarily through minimum size requirements typically based on age or size of maturation. The traditional management paradigm of size selective harvesting is coming under increased pressure (Zhou et al. 2010, Garcia et al. 2012) as fisheries managers and scientists look for viable alternatives to shift from single to multi-species management. A growing number of empirical (Jul-Larsen 2003) and theoretical (Law et al. 2012, Jacobsen et al. 2014) studies indicate that unselective balanced harvesting may be a more desirable strategy which can retain a larger proportion of older individuals in the population while still maintaining high yields. The negative correlation between herring abundance and bluefin tuna weight suggest such a balanced, unselective harvesting strategy may be beneficial for predators such as bluefin tuna which pursue and consume one prey item at a time and require high energy intake. In this paper, we do not attempt to explain the mechanisms leading to changes in size structure of herring in the Gulf of Maine. Studies on components of this assemblage on George's Bank suggest the shift to a smaller herring community (as indicated in the negative relationship between herring size and abundance) is a direct result of density dependent growth (Melvin \& Stephensen 2007). Increased fishing pressure can reduce density dependence and potentially lead to more positive weight anomalies for these small pelagics. However, intense fishing also reduces the abundance of older, larger fish, and management strategies that produce a high abundance of faster growing but smaller individuals would shift the size spectrum towards smaller fish. By altering the size spectrum and the abundance of the prey species, different management options would favor one predator type over another. For example, humpback whales that feed on schools of herring rather than individual fish should be more sensitive to total herring biomass. There is evidence that the Gulf of Maine became a more important foraging ground for humpback whales following the increase in herring abundance during the 1990s (Weinrich et al. 1997). Our work suggests that indicators of size structure and body condition should 
be considered when managing prey species to ensure higher predator fitness. The challenge will be implementing such a strategy within the context of current assessments and management models and determining the relative importance of prey abundance and size for a range of predators with different foraging strategies and metabolic needs.

Acknowledgements. We thank the New England bluefin tuna spotter pilots and commercial bluefin tuna fishermen for providing us access to their fishing logbooks. We are particularly grateful to Robert Campbell, whose attention to detail and excellent logbooks brought the changes in condition of bluefin tuna to our attention. We thank the NMFS for access to the US bluefin tuna landings database, and the Maine Department of Marine Resources for providing us with the commercial Atlantic herring biological sampling database. We also thank the Canadian Department of Fisheries and Oceans for access to the Atlantic herring biological sampling database. This work was made possible through a Comparative Analysis of Marine Ecosystems (CAMEO) grant from the National Science Foundation and the NMFS to A.J.P. (OCE 1041731).

\section{LITERATURE CITED}

Alder J, Campbell B, Karpouzi V, Kaschner K, Pauly D (2008) Forage fish: from ecosystems to markets. Annu Rev Environ Resour 33:153-166

Bakun A, Broad K (2003) Environmental 'loopholes' and fish population dynamics: comparative pattern recognition with focus on El Niño effects in the Pacific. Fish Oceanogr 12:458-473

Bestor TC (2004) Tsukiji: the fish market at the center of the world. University of California Press, Berkeley and Los Angeles, CA

Block BA, Teo SLH, Walli A, Boustany A and others (2005) Electronic tagging and population structure of Atlantic bluefin tuna. Nature 434:1121-1127

Boyd IL, Wanless S, Camphuysen CJ (eds) (2006) Top predators in marine ecosystems: their role in monitoring and management. Cambridge University Press, Cambridge

Brill R (1996) Selective advantages conferred by the high performance physiology of tunas, billfishes, and dolphin fish. Comp Biochem Physiol 113:3-15

Butler CM, Rudershausen PJ, Buckel JA (2010) Feeding ecology of Atlantic bluefin tuna (Thunnus thynnus) in North Carolina: diet, daily ration, and consumption of Atlantic menhaden (Brevoortia tyrannus). Fish Bull 108:56-69

Chapman EW, Jørgensen C, Lutcavage ME (2011) Atlantic bluefin tuna (Thunnus thynnus): a state-dependent energy allocation model for growth, maturation, and reproductive investment. Can J Fish Aquat Sci 68:1934-1951

Chase BC (2002) Differences in the diet of Atlantic bluefin tuna (Thunnus thynnus) at five seasonal feeding grounds on the New England continental shelf. Fish Bull 100: 168-180

Chavez FP, Ryan J, Lluch-Cota SE, Niquen C (2003) From anchovies to sardines and back: multi decadal change in the Pacific Ocean. Science 299:217-221

Cury P, Bakun A, Crawford RJM, Jarre-Teichmann A, Quinones R, Shannon LJ, Verheye HM (2000) Small pelagics in upwelling systems: patterns of interaction and structural changes in 'wasp-waist' ecosystems. ICES J Mar Sci 57:603-618
Diamond AW, Devlin CM (2003) Seabirds as indicators of changes in marine ecosystems: ecological monitoring on Machias Seal Island. Environ Monit Assess 88:153-175

Estrada JA, Lutcavage M, Thorrold SR (2005) Diet and trophic position of Atlantic bluefin tuna (Thunnus thynnus) inferred from stable carbon and nitrogen isotope analysis. Mar Biol 147:37-45

Fitzgibbon QP, Baudette RV, Musgrove RJ, Seymour RS (2008) Routine metabolic rate of southern bluefin tuna (Thunnus maccoyii). Comp Biochem Physiol A Comp Physiol 150:231-238

Frederiksen M, Wanless S, Harris MP, Rothery P, Wilson LJ (2004) The role of industrial fisheries and oceanographic change in the decline of North Sea black-legged kittiwakes. J Appl Ecol 41:1129-1139

Furness RW (2002) Management implications of interactions between fisheries and sandeel-dependent seabirds and seals in the North Sea. ICES J Mar Sci 59:261-269

Galuardi B, Royer R, Golet W, Logan J, Neilson J, Lutcavage M (2010) Complex migration routes of Atlantic bluefin tuna (Thunnus thynnus) question current population structure paradigm. Can J Fish Aquat Sci 67:966-976

> Garcia SM, Kolding J, Rice J, Rochet MJ and others (2012) Reconsidering the consequences of selective fisheries. Science 335:1045-1047

> Giacomini HC, Shuter B, Lester N (2013) Predator bioenergetics and the prey size spectrum: Do foraging costs determine fish production? J Theor Biol 332:249-260

Golet W, Cooper A, Campbell R, Lutcavage M (2007) Decline in condition of Atlantic bluefin tuna in the Gulf of Maine. Fish Bull 105:390-395

> Golet WJ, Galuardi B, Cooper AB, Lutcavage ME (2013) Changes in the distribution of Atlantic bluefin tuna (Thunnus thynnus) in the Gulf of Maine 1979-2005. PLoS ONE 8:e75480.

Greene CH, Meyer-Gutbrod E, Monger BC, McGarry LP and others (2013) Remote climate forcing of decadalscale regime shifts in the Northwest Atlantic shelf ecosystems. Limnol Oceanogr 58:803-816

Gutenkunst R, Newlands N, Lutcavage M, EdelsteinKeshet L (2007) Inferring resource distributions from Atlantic bluefin tuna movement: An analysis based on net displacement and length of track. J Theor Biol 245: 243-257

Hamming RW (1973) Numerical methods for scientists and engineers. McGraw-Hill, New York, NY

Hanke AR, Neilson JD (2011) Catch rate standardization for the Canadian southern Gulf of St. Lawrence bluefin tuna fishery, 1981 to 2009. Collect Vol Sci Pap ICCAT 66: 762-774

Hanke AR, Andrushchenko I, Neilson J, Whelan C (2013) Indices of stock status from the Canadian bluefin tuna fishery. Collect Vol Sci Pap ICCAT 69:335-377

Hastie T, Tibshirani R (1990) Generalized additive models. Chapman \& Hall, London

ICCAT (2010) Report of the 2010 Atlantic bluefin tuna stock assessment session (Madrid, Spain, 6-12 September 2010) Collect Vol Sci Pap ICCAT 67:505-714

Jacobsen NS, Gislason H, Andersen KH (2014) The consequences of balanced harvesting of fish communities. Proc R Soc Lond B Biol Sci 281:20132701

Jennings S, Kaiser MJ, Reynolds JD (2001) Marine fisheries ecology. Blackwell, Oxford

Jørgensen C, Ernande B, Fiksen O, Diekmann U (2006) The logic of skipped spawning in fish. Can J Fish Aquat Sci 63:200-211

Jul-Larsen E 2003 Management, co-management or no management? Major dilemmas in southern African fresh- 
water fisheries 2: case studies. FAO Fish Tech Paper 426/2. FAO, Rome

Kjesbu OS, Klungsoeyr J, Kryvi H, Witthames PR, Greer Walker M (1991) Fecundity, atresia, and egg size of captive Atlantic cod (Gadus morhua) in relation to proximate body composition. Can J Fish Aquat Sci 48:2333-2343

Knapp JM, Aranda G, Medina A, Lutcavage M (2014) Comparative assessment of the reproductive status of female Atlantic bluefin tuna from the Gulf of Mexico and the Mediterranean Sea. PLoS ONE 9:e98233.

> Lambert Y, Dutil JD (2000) Energetic consequences of reproduction in Atlantic cod (Gadus morhua) in relation to spawning level of somatic energy reserves. Can J Fish Aquat Sci 57:815-825

Lane HA, Westgate AJ, Koopman HN (2011) Ontogenetic and temporal variability in the fat content and fatty acid composition of Atlantic herring (Clupea harengus) from the Bay of Fundy Canada. Fish Bull 109:113-122

> Law R, Plank MJ, Kolding J (2012) On balanced exploitation of marine ecosystems: results from dynamic size spectra. ICES J Mar Sci 69:602-614

> Lawson JW, Magalhães AM, Miller EH (1998) Important prey species of marine vertebrate predators in the northwest Atlantic: proximate composition and energy density. Mar Ecol Prog Ser 164:13-20

> Lehodey P, Chai F, Hampton J (2003) Modeling climaterelated variability of tuna populations from a coupled ocean-biogeochemical-populations dynamics model. Fish Oceanogr 12:483-494

Logan JM, Golet WJ, Lutcavage ML (in press) (2014) Diet and condition of Atlantic bluefin tuna (Thunnus thynnus) in the Gulf of Maine 2004-2008. Environ Biol Fishes 98:1411-1430

Maravelias CD, Reida DG, Swartzmanb G (2000) Modeling the spatio-temporal effects of environment on Atlantic herring Clupea harengus. Environ Biol Fishes 58:157-172

> Marshall CT, Yaragina NA, Lambert Y, Kjesbu OS (1999) Total lipid energy as a proxy for total egg production by fish stocks. Nature 402:288-290

Mather FJ, Schuck HA (1960) Growth of bluefin tuna of the western North Atlantic. Fish Bull 179:39-52

Mather FJ, Mason JM, Jones A (1995) Historical document: life history and fisheries of Atlantic bluefin tuna. NOAA Tech Memo NMFS-SEFSC-370. National Marine Fisheries Service, Miami, FL

Medina A, Abascal FJ, Megina C, Garcia A (2002) Stereological assessment of reproductive status of female Atlantic northern bluefin tuna during migration to the Mediterranean spawning grounds through the Strait of Gibraltar. J Fish Biol 60:203-217

Melvin GD, Stephensen RL (2007) The dynamics of a recovering fish stock: Georges Bank herring. ICES J Mar Sci 64:69-82

> Myers RA, Worm B (2003) Rapid worldwide depletion of predatory fish communities. Nature 423:280-283

Olson RJ (1982) Feeding and energetic studies of yellowfin tuna, food for ecological thought. Collect Vol Sci Pap ICCAT 17:444-457

Österblom H, Olsson O, Blenckner T, Furness RW (2008) Junk-food in marine ecosystems. Oikos 117:967-977

Overholtz WJ (2006) Estimates of consumption of Atlantic herring (Clupea harengus) by bluefin tuna (Thunnus thynnus) during 1970-2002: an approach incorporating uncertainty. J Northwest Atl Fish Sci 36:55-63

Overholtz WJ, Friedland KD (2002) Recovery of the Gulf of Maine-Georges Bank Atlantic herring (Clupea harengus) complex: perspectives based on bottom trawl survey data. Fish Bull 100:593-608
Parrack ML, Phares PL (1979) Aspects of the growth of Atlantic bluefin tuna determined from mark-recapture data. Collect Vol Sci Pap ICCAT 8:356-366

> Pazzia I, Trudel M, Ridgway M, Rasmussen JB (2002) Influence of food web structure on the growth and bioenergetics of lake trout (Salvelinus namaycush). Can J Fish Aquat Sci 59:1593-1605

Pikitch E, Boersma PD, Boyd IL, Conover DO and others (2012) Little fish, big impact: managing a crucial link in ocean food webs. Lenfest Ocean Program, Washington, DC

Pikitch EK, Rountos KJ, Essington TE, Santora C and others (2014) The global contribution of forage fish to marine fisheries and ecosystems. Fish Fish 15:43-64

Pleizier NK, Campana SE, Schallert RJ, Wilson SG, Block B (2012) Atlantic bluefin tuna (Thunnus thynnus) diet in the Gulf of St. Lawrence and on the eastern Scotian Shelf. J Northwest Atl Fish Sci 44:67-76

Randall CK, Zentall TR (1997) Win-stay/lose-shift and winshift/lose-stay learning by pigeons in the absence of overt response mediation. Behav Processes 41:227-236

Rideout RM, Rose GA, Burton MPM (2005) Skipped spawning in female iteroparous fishes. Fish Fish 6:50-72

- Rosen DAS, Trites AW (2004) Satiation and compensation for short-term changes in food quality and availability in young Steller sea lions (Eumetopias jubatus). Can J Zool 82:1061-1069

> Scott BE, Marteinsdottir G, Begg GA, Wright PJ, Kjesbu OS (2006) Effects of population size/age structure, condition and temporal dynamics of spawning on reproductive output in Atlantic cod (Gadus morhua). Ecol Model 191: 383-415

Sherwood GD, Pazzia I, Moeser A, Hontela A, Rasmussen JB (2002) Shifting gears: enzymatic evidence for the energetic advantage of switching diet in wild-living fish. Can J Fish Aquat Sci 59:229-241

Sibert J, Hampton J, Kleiber P, Maunder M (2006) Biomass, size, and trophic status of top predators in the Pacific Ocean. Science 314:1773-1776

Spitz J, Trites AW, Becquet V, Brind'Amour A, Cherel Y, Galois R, Ridoux V (2012) Cost of living dictates what whales, dolphins and porpoises eat: the importance of prey quality on predator foraging strategies. PLoS ONE 7:e50096

Stephens DW, Krebs JR (1986) Foraging theory. Princeton University Press, Princeton, NJ

Tacon AGJ, Metian M (2009) Fishing for feed or fishing for food: increasing global competition for small pelagic forage fish. Ambio 38:294-302

TRAC (2009) Gulf Of Maine-Georges Bank Herring Stock Complex. TRAC Status Report 2009/04. Available at www.asmfc.org/uploads/file/09TRACsummaryReport.pdf

> Vert-pre KA, Amoroso RO, Jensen OP, Hilborn R (2013) Frequency and intensity of productivity regime shifts in marine fish stocks. Proc Natl Acad Sci USA 110: 1779-1784

Weinrich M, Martin M, Griffiths R, Bove J, Schilling MA (1997) Shift in distribution of humpback whales, Megaptera novaeangliae, in response to prey in the southern Gulf of Maine. Fish Bull 95:826-836

Wilson SG, Lutcavage ME, Brill RW, Genovese MP, Cooper AB, Everly AW (2005) Movements of bluefin tuna (Thunnus thynnus) in the northwestern Atlantic Ocean recorded by pop-up satellite archival tags. Mar Biol 146:409-423

Zhou S, Smith ADM, Punt AE, Richardson AJ and others (2010) Ecosystem-based fisheries management requires a change to the selective fishing philosophy. Proc Natl Acad Sci USA 107:9485-9489 